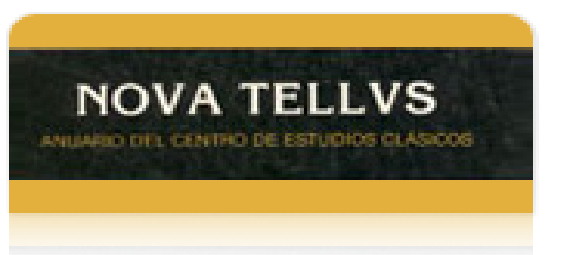

Nova Tellus

ISSN: 0185-3058

novatelu@servidor.unam.mx

Centro de Estudios Clásicos

México

Figueroa Castro, Óscar

El arte de la interpretación en la India sánscrita: orígenes y desarrollo

Nova Tellus, vol. 31, núm. 1, 2013, pp. 9-34

Centro de Estudios Clásicos

Distrito Federal, México

Disponible en: http://www.redalyc.org/articulo.oa?id=59137771001

- Cómo citar el artículo

- Número completo

- Más información del artículo

- Página de la revista en redalyc.org

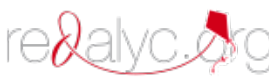

Sistema de Información Científica

Red de Revistas Científicas de América Latina, el Caribe, España y Portugal Proyecto académico sin fines de lucro, desarrollado bajo la iniciativa de acceso abierto 


\title{
El arte de la interpretación en la India sánscrita: orígenes y desarrollo
}

The Art of Interpretation in Sanskritic India:

Origins and Development

\author{
Óscar Figueroa CASTRO \\ Universidad Nacional Autónoma de México \\ figueroa@correo.crim.unam.mx
}

\begin{abstract}
RESUMEN: Basado en una amplia selección de fuentes primarias y secundarias, el presente ensayo revisa la función capital que la actividad exegética y la literatura de comentarios desempeñó para el desarrollo y la identidad de la cultura sánscrita a lo largo de más de dos milenios. A fin de explicar la riqueza y, sobre todo, la continuidad del ars interpretandi sánscrito, el ensayo propone como tesis la necesidad de acudir al pasado védico y revisar un doble legado: por un lado, la relación entre interpretación y revelación; por el otro, entre interpretación y liturgia.
\end{abstract}

ABSTRACT: Based on a rich selection of primary and secondary sources, this paper discusses the fundamental role that exegesis and commentarial literature played in the development and identity of Sanskrit culture throughout more than two millennia. In order to understand the richness and, above all, the continuity of Sanskrit ars interpretandi, the article argues for the necessity of going back to the Vedic period and retrieve a double legacy: on the one hand, the relationship between interpretation and revelation; on the other, between interpretation and liturgy.

PALABRAS ClAVE: cultura sánscrita, Palabra, ars interpretandi, Vedas.

KEYWORDS: Sanskrit culture, Word, ars interpretandi, Vedas.

RECIBIDO: 16 de noviembre de 2012 • ACEPTADO: 20 de junio de 2013.

Le commentaire cherche, en énonçant ce qui a été dit, à redire ce qui n'a jamais été prononcé.

M. Foucault, Naissance de la clinique, p. xiii

Preámbulo: cultura sánscrita y tradición exegética

Común es la idea que se tiene de la antigua cultura de la India, la India sánscrita, como depositaria de sacratísimas revelaciones, proezas literarias sin paralelo, relatos sobre estados sublimes y visiones de planos sobrenaturales. Menos conocido es, sin embargo, el hecho de que el grueso de su literatura especulativa se compone de obras exegéticas. Trátese, entre los hinduistas, de Śamkara (siglos VII-VIII), Kumārila 
Bhatța (siglo VIII) o Abhinavagupta (siglo X); de Candrakīrti (siglo VII) y Dharmakīrti (siglo VII), entre los budistas, o de Hemacandra (siglo XII), entre los jainas, la obra de la mayoría de las mentes más lúcidas de la especulación sánscrita en realidad está conformada por trabajos exegéticos y comentarios. Más aún, la centralidad de la interpretación como forma de pensar y como género literario está presente en prácticamente todos los campos del saber, no sólo en el ámbito filosófico-religioso (como es de esperarse), sino en general en la literatura científica (śāstra) e incluso en la poesía (kāvya). Así, desde una época temprana la teoría literaria, la tradición legalista, la medicina o la teoría sobre el ritual, por poner algunos ejemplos notables, confiaron sus descubrimientos al arte de la interpretación y presentaron buena parte de sus resultados bajo ese formato. Comentarios en todas sus variantes: los hay, desde luego, a textos revelados, pero existen asimismo comentarios a otros comentarios en una secuencia que puede extenderse por varios siglos; hay además auto-comentarios; unos están escritos en prosa, otros en verso, y algunos más combinan ambos registros. Si bien "en mayor o menor medida la tarea principal de todo comentario es explicar expresiones individuales en un texto, buscando con ello esclarecer su sintaxis y ofrecer paráfrasis de sus componentes léxicos, frases u oraciones", ${ }^{1}$ los objetivos específicos en cada caso pueden variar enormemente. Mientras algunos tienen como propósito hacer explícito o ampliar (prapañcaka) el mensaje de textos caracterizados por la concisión y aun la secrecía - notablemente sūtra-s y kārik $\bar{a}$-s, esto es, secuencias de fórmulas aforísticas que condensan toda una doctrina-; otros, en cambio, analizan desde una perspectiva crítica ciertos pasajes difíciles o controversiales. Algunos exhiben un tono polémico e incluso, a partir del desarrollo de la lógica durante los primeros siglos de la era común, están redactados a manera de debates ${ }^{2}$ otros son, por el contrario, muy didácticos, escritos casi como manuales de escuela $^{3}$ limitándose a ofrecer sinónimos palabra por palabra y cubrir lagunas de orden gramatical o semántico sólo ahí donde sea necesario

${ }^{1}$ Ganeri 2008, p. 108.

${ }^{2}$ Volveré a este aspecto al final del ensayo.

${ }^{3}$ De un modo no muy distinto a los hypomnemata o commentarii del periodo helenístico y la Antigüedad tardía. Al respecto véase Hadot 2002, p. 184. 
con base en las expectativas ( $\bar{a} k \bar{a} \dot{n} k s ̣ \bar{a})$ del lector. ${ }^{4}$ Algunos aspiran a revelar el mensaje oculto de una obra y con ese fin optan por la alegoría como recurso explicativo; a otros en cambio les interesa recoger y reconciliar las opiniones de distintas autoridades dentro de una escuela o tradición, proyectando así una imagen de continuidad y estabilidad, y con ese objetivo abrazan la dialéctica como la mejor estrategia discursiva.

Por otra parte, la enmienda e incluso reconstrucción de diversos textos fundacionales $(m \bar{l} l a)$ ha sido posible gracias a las observaciones de generaciones de exegetas. Por ejemplo, sin el comentario de Arcata (siglo VIII) sería muy deficiente nuestro conocimiento del Hetubindu, importante tratado del gran filósofo budista Dharmakīrti (siglo VII). Encima, la difícil tarea de reconstruir el desarrollo histórico de doctrinas o corrientes de pensamiento ha dependido en buena medida del testimonio de diversos comentaristas. Entonces, por poner un par de ejemplos bien conocidos, para comprender la evolución del sistema Sāṃkhya, resulta indispensable acudir al Yuktidīpika, ${ }^{5}$ extenso comentario, rico en referencias históricas, a la Sāmkhyakārikā de İ́sarakṛșna; y lo mismo vale, en el caso de la escuela Mīmāṃsā, para el comentario de Śabara (el Śābarabhāṣya) al Mìmāmsāāūtra. Por último, es también gracias a la figura del comentarista que el especialista contemporáneo puede trazar la historia de la recepción de autores clásicos, por ejemplo Kālidāsa, dentro de la propia literatura sánscrita.

Paradójicamente, al mismo tiempo es mucho lo que ignoramos sobre tan profuso y complejo género, de entrada porque existe un sinfín de voces para decir "comentario" en sánscrito. Destacan por ejemplo bhāṣya, vārttika, vrtti, vivrti, țik $\bar{a}$, vyākhyāna, vivaraṇa, o también, en un sentido más poético, prakāśa, darpana, locana, candrikā y muchos otros, y aun-

${ }^{4}$ En este sentido no debe pasarse por alto la posibilidad de que el género haya tenido tanto su origen como su posterior impacto en la forma misma de enseñar y aprender sánscrito. Como se sabe, en los niveles avanzados, luego de que el estudiante ha memorizado un número formidable de paradigmas y listas de palabras, el sistema tradicional de enseñanza de la lengua se basa en "parafrasear" textos, la forma más elemental de interpretación, y es parafraseando que ese estudiante demuestra haber comprendido la gramática, la sintaxis y el sentido de cada oración en un texto. Al respecto véase Gerow 2002; también Tubb 2007, pp. 1-12.

5 Tal como lo demuestran las dos grandes y hoy legendarias monografías sobre la materia: por un lado, Chakravarti 1951; por el otro, la extensa sección que Frauwallner 1953, vol. 1, dedica al Sāṃkhya. 
que la mayoría de los especialistas coincide en que esta riqueza apunta a algo más que un mero fenómeno de sinonimia, son muchas las dudas que aún prevalecen sobre el sentido específico que posee cada uno de estos términos, así como sobre su genealogía y evolución semántica. ${ }^{6}$

Ahora bien, la consolidación del ars interpretandi en la India obedeció en buena medida al propio desarrollo de la cultura clásica sánscrita, ${ }^{7}$ a partir de los primeros siglos de nuestra era y hasta antes de la penetración definitiva del islam hacia el siglo XII, esto es, aproximadamente el periodo que el Occidente europeo conoce como Edad Media. Durante este extenso lapso de tiempo tuvo lugar en la India un intenso proceso de refinamiento intelectual en todos los ámbitos del saber, lo que supuso, entre otras cosas, la formalización de las estrategias discursivas empleadas por las distintas escuelas con el fin de diseminar y defender sus ideas, buscando así validez universal, es decir, credibilidad más allá del círculo de adeptos. A partir de entonces escépticos y brahmanes ortodoxos, budistas y jainas, teístas y ateos, dualistas y monistas expondrían sus planteamientos en respuesta a sus oponentes y conforme a las normas establecidas para esta peculiar forma de escolástica. Y para una tarea así, por ejemplo defender la eficacia del ritual o la verdad de la fe, era necesario no sólo un uso persuasivo de la razón, sino además herramientas concretas. Así, en lo que constituye algo así como el trivium de la cultura medieval sánscrita, los intelectuales indios abrazaron la gramática (vyakāraṇa), la lógica (nyāya) y el arte de la interpretación como disciplinas fundamentales.

Desde luego, los orígenes de este último se remontan a las antiguas técnicas encaminadas a comprender correctamente el significado de las invocaciones y las prescripciones védicas. Fue sólo más tarde, en los últimos siglos antes de la era común, que ese conjunto de técnicas fue organizado alrededor de toda una disciplina. Suele darse a ésta el nombre genérico de mìmāmsāa, literalmente "análisis". Si bien este tipo de análisis siguió siendo concebido como una prolongación de la exégesis védica, y como tal su principal preocupación fue comprender y proteger

6 Debemos a Ganeri 2008 y Preisendanz 2008, los esfuerzos más logrados para tratar de comprender la función y el alcance detrás de tan variada nomenclatura. Sus observaciones, sin embargo, se centran exclusivamente en el comentario filosófico. Los esfuerzos previos de J. Bronkhorst son también iluminadores en algunos respectos. Véase Bronkhorst 1990 y 1991.

${ }^{7}$ Lo que algunos llaman de hecho la "sanscritización" de la India. Al respecto véase Pollock 2006, caps. 1-5. 
la verdad de las escrituras, con el tiempo las implicaciones de dicha reflexión permitieron el desarrollo de una serie de doctrinas en torno a la naturaleza del habla, la acción, el destino del hombre y muchas otras, rebasando así su limitado entorno ortodoxo e influyendo al resto de las escuelas, por entonces también en formación.

Así las cosas, para apreciar con elementos suficientes el desarrollo de la interpretación sánscrita en general, así como el auge sin precedentes que alcanzó la literatura de comentarios, es necesario remitirnos a su pasado védico, en cuyo seno fueron prefiguradas sus principales premisas y aspiraciones. Al respecto sobresalen dos aspectos. En primer lugar, que debamos a la tradición védica los primeros intentos encaminados a formalizar el ars interpretandi en la India nos lleva a la profunda relación que existe en esta cultura entre revelación e interpretación, entre la Palabra trascendente y la palabra humana, relación, como veremos, con un fuerte componente crítico contra los alcances de la razón. En segundo lugar destaca la naturaleza idiosincrásicamente ritual de la Palabra revelada, hecho que, como mostraré, acaba dándole también un carácter ritual a la interpretación.

Cumplido este primer propósito, el que concierne a los orígenes, estaremos en condiciones de revisar la fase madura de la tradición exegética sánscrita. Como veremos, entre uno y otro momento existen importantes elementos de continuidad, incluso en medio de las diferencias en los detalles. Entonces, por un lado, el valor superlativo otorgado a la Palabra revelada reaparecerá en el valor y la autoridad otorgados a ciertas figuras, cuya palabra es así elevada a canon. Por el otro, el componente litúrgico de la exégesis védica reaparecerá en la cultura del debate que da identidad al periodo clásico.

\section{En el principio fue la Palabra: revelación e interpretación}

Como P.-S. Filliozat ha observado, el hecho de que en la India la actividad intelectual surgió y floreció no sólo a partir de una profunda toma de conciencia sobre la naturaleza del lenguaje (la tradición gramatical), sino asimismo alrededor de disciplinas cuyo propósito fue comprender e interpretar lo enunciado, "explica el extraordinario desarrollo, tanto en número como en sofisticación, de la literatura de comentarios". ${ }^{8} \mathrm{Si}$ a este hecho agregamos el elemento de sacralidad, esto es, la percepción

${ }^{8}$ Filliozat 1992, p. 45. 
que en ciertas esferas se tiene de los textos como manifestaciones de una Palabra primordial o trascendente $(v \bar{a} c)$, la imagen del intelectual indio como exegeta resulta todavía más definitiva.

Los rudimentos de esta actitud hacia el texto sagrado se asoman con insistencia en los Brāhmaṇa-s, vasto corpus en prosa redactado a fin de instruir a los sacerdotes y recitadores védicos en el significado de la liturgia. Fue dentro de este marco general que el hombre védico fue configurando una serie de estructuras básicas y reglas lo suficientemente consistentes para transformar la reflexión sobre la Palabra en un evento interpretativo. Las especulaciones de las Upanișad-s simplemente cristalizan, en algunos casos con profundas implicaciones de orden filosófico y soteriológico, la apuesta interpretativa de los Brāhmaṇa-s. Este sentido de consumación puede apreciarse, por ejemplo, a partir del valor que se otorga al ars interpretandi en tanto herencia transmitida. ${ }^{9}$

La exégesis es ahora toda una tradición y como tal goza de reconocimiento y autoridad. Está al servicio de la ortodoxia y es ella misma un arte ortodoxo. ¿Cuál es el núcleo de esta ortodoxia, sobre qué fundamento descansa? Ya lo dijimos. Descansa sobre la autoridad absoluta - por encima incluso de los dioses - atribuida a la Palabra increada, los Vedas, concebidos como epifanía primordial y eje del orden social y cósmico.

Así pues, que entre las diversas escuelas y corrientes del hinduismo ser ortodoxo (āstika) dependa de una obediencia a la Palabra de los Vedas, sea esto por convencimiento propio o legado directo (las escuelas Mīmāṃsā y Vedānta, por ejemplo), o, en retrospectiva y apologéticamente con el fin de ganar credibilidad (las escuelas Nyāya y Vaiśeșika, por ejemplo), significa entonces, por extensión, un gesto compartido de confianza en la interpretación como la vía más apta para desentrañar los misterios de la Palabra, así como para legitimar las propias ideas al respecto.

En cualquiera de estos casos el punto de partida, se haga éste explícito o no, es que la verdad no se construye a partir de recursos propios, pues está dada de antemano en los himnos y admoniciones védicas, si bien de manera codificada o de un modo que rebasa la capacidad de la razón para aprehenderla de una vez por todas. Frente a la innegable presencia de la Palabra sagrada a nosotros sólo nos queda interpretar - éste es, de hecho, el sentido más profundo de la noción de apauruṣeya, es decir, la

${ }^{9}$ Véase, por ejemplo, la genealogía o línea de transmisión (vaṃśa) que en sus últimas líneas ofrece la Bṛhadāraṇyaka Upaniṣad para sus enseñanzas. 
“ausencia de autor" para la revelación védica.

Lo crucial aquí es, no obstante, que la presencia (la primacía de la revelación sobre el hombre) es al mismo tiempo una ausencia (la imposibilidad de constituir conceptualmente esa presencia). Y es aquí donde lo ortodoxo, la confianza absoluta en la preeminencia de la revelación, atrae para sí casi de manera natural la noción de secreto. Este misterio significa, para la labor interpretativa, un ejercicio sin fin, plural, y aun negativo; de ahí que interpretar se parezca más a un buscar que a un explicar; que sea más perseguir cierto fin que de-finir.

No extraña entonces que Yāska, autor del Nirukta y uno de los más antiguos exegetas védicos de que tenemos noticia, tal vez contemporáneo del gramático Pāninini (aprox. siglo v a. C.), reconozca como rasgo distintivo la polivalencia semántica (anekārthatā) de los Vedas, admitiendo con ello una interpretación también plural, abierta a registros variados e incluso contradictorios. ${ }^{10}$

Entonces, en este caso no es la primacía del saber sobre el objeto por conocer lo que establece las condiciones necesarias para la constitución e inteligibilidad de dicho objeto. ${ }^{11}$ Las condiciones no las establece aquí el sujeto, sino la Palabra increada que se presenta sin más, de manera incondicional y antes de cualquier determinación subjetiva, resistiéndose entonces ella misma a ser objeto. El oficio de intérprete se vuelve necesario justamente cuando el fenómeno que se busca entender se resiste a ser objeto y, no obstante, aparece, se muestra o revela. Esta anticipación viene además a poner en entredicho mi identidad como sujeto. Lo que en esencia pueda ser se cifra ahora en el misterio de la revelación. Aceptar hasta sus últimas consecuencias esta disposición, que es ya un descentramiento, tal es el principio que guía al arte de la interpretación, transformando la búsqueda de lo infinito al interior del texto en una búsqueda infinita, y como tal más próxima a la recreación ritual que a la explicación lógica.

Si la Palabra sagrada fuese un evento constituido conceptualmente no

${ }^{10}$ Véase Nirukta 2.27: “Los [objetos] han de interpretarse conforme al significado [de las palabras que los designan]. Si su sentido es uniforme, la interpretación será [también] uniforme; [empero,] si caben varios sentidos, la interpretación será múltiple" (tāni cet samānakarmāṇi samānanirvacanāni | nānākarmāṇi cen nānānirvacanāni yathārthạ̣ nirvaktavyāni). Véase asimismo 1.14, entre muchos otros pasajes donde este principio es aplicado.

${ }^{11}$ Dicho con Kant, donde las condiciones a priori de posibilidad de toda experiencia son también las condiciones de posibilidad de los objetos de esa experiencia. 
habría necesidad de interpretar. Sin embargo, su precedencia respecto a toda conceptualización demanda una respuesta que es también una actitud: la del creyente y su firme adhesión a una particular visión orgánica del mundo. No sorprende entonces que entre las diferentes clases de ignorancia que al inicio del Tantrasāra enumera Abhinavagupta, el gran exegeta del siglo $\mathrm{x}$, se encuentre una paradójica "ignorancia intelectual" (buddhigatam ajñānam), definida precisamente ya sea como "incredulidad" (aniścaya) o como "falsa creencia" (viparītaniścaya). ${ }^{12}$ El lenguaje religioso no le habla, en primera instancia, a quien es presa de dudas y por lo tanto carece de convicción (prasiddhi). ${ }^{13}$ Como veremos, tal convicción conlleva en última instancia un profundo escepticismo respecto a los alcances de una razón emancipada.

\section{Empero, la Palabra es acto: ritual e interpretación}

En la India antigua, la Palabra es concebida sobre todo como un evento oral, esto es, para ser escuchado. De ahí el famoso nombre dado a los Vedas, śruti, literalmente "audición”. Hay, pues, revelación, mas no Libro. Esto fue así incluso después de que paulatinamente se extendiera el uso de la escritura (en los primeros siglos de nuestra era), e incluso después de la producción masiva de manuscritos (a partir de los siglos XIIXIII). Antes que signo grabado en la piedra o trazo en el papel, la revelación es un evento fonético. No sólo eso. Como apenas sugerí, de igual relevancia es el carácter ritual de ese evento. La revelación reverbera, se deja escuchar e impone su verdad a través de una serie de movimientos corporales y gesticulaciones, mediante la manipulación de una amplia variedad de sustancias, en medio del bisbiseo del fuego y el crujir de las oblaciones. En la India, la revelación es un acto, una representación ritual del sacrificio original, y en esa medida se manifiesta a través de usos performativos del habla: invocaciones para alabar a los diferentes dioses y prescripciones que conminan a actuar. ${ }^{14}$

12 Tantrasāra 1: "Existen dos tipos de ignorancia: intelectual y ordinaria. De éstas, la ignorancia intelectual consiste en incredulidad o falsas creencias" (dvividham ca ajñānam buddhigatam paurușam ca. tatra buddhigatam aniścayasvabhāvam viparìtaniścayātmakam ca).

${ }^{13}$ Cf. Abhinavagupta 1986, vol. III, p. 96.

${ }^{14}$ En cuanto a este último aspecto, no es de extrañar entonces que en una medida importante la filosofía del lenguaje desarrollada por la escuela Mīmāṃsā gire alrededor 
La interpretación tiene entonces una función doble: no sólo como herramienta para comprender la Palabra sacra sino ahí mismo para comprender la íntima conexión entre ésta y los actos que la ponen en escena. Si bien es a través de un acto hermenéutico que la dimensión teísta del ritual puede transformarse en argumento teológico, el ídolo en discurso, hay que añadir que es también a través de un acto hermenéutico que el argumento teológico se reviste de la naturaleza dinámica, performativa, del ritual. La celebración puntual de ritos (y ahí mismo la obediencia a un canon tenido como revelado) y la apropiación interpretativa de tales actos (y ahí mismo la innovación especulativa) no son tareas incompatibles; antes bien, acontecen necesariamente unidas. En suma, la posibilidad de una interpretación que deriva sus estrategias del continuum de la actividad litúrgica, esto es, donde el paradigma no es la sustancia sino la actividad, no parece ser asunto nimio. Al respecto quisiera detenerme en el componente crítico que esta exégesis ritualizada proyecta contra el esencialismo metafísico.

En efecto, que la tarea interpretativa se inspire en la naturaleza performativa de la revelación crea las condiciones para desarrollar un discurso también centrado en la acción y las relaciones. Así, las sospechas que sobre el lenguaje predicativo proyecta la exégesis sánscrita tienen una razón más profunda: predicar es determinar la realidad con base a criterios metafísicos. Veamos el ejemplo concreto de la tradición ortodoxa Mīmāṃsā.

De acuerdo con Jaimini (aprox. siglo II a. C.), el legendario autor del Mìmāms āsūtra, existe una distinción fundamental entre existencia ordinaria, la esfera del conocimiento convencional, y existencia litúrgica. Como explica F. Clooney, ${ }^{15}$ cuando un objeto entra al espacio del sacrificio o cuando se ejecuta una acción conforme a las prescripciones védicas, ese objeto experimenta bhâva, esto es, pasa de la existencia ordinaria (sat, vidyāmana) a una existencia de orden superior, donde queda al amparo de una red de analogías (upanișad) entre los actos y las palabras, asociaciones que no tienen paralelo y de hecho resultan absurdas en la existencia ordinaria. ${ }^{16}$ Jaimini no está, pues, interesado

del modo imperativo.

15 Véase en especial Clooney 1990, pp. 195-202.

16 “Analogía”, "relación” o “conexión”, tal es, en efecto, el significado de la insigne palabra upaniṣad. La recepción popular (y romántica) del término como "enseñanza mís- 
en la existencia estática (sat), ni en alcanzar, al fondo de la realidad cambiante, la sustancia inmutable y eterna, la estabilidad de una supuesta esencia interior (ätman). Lo que le interesa es, en cambio, el acontecer de lo nuevo, aquello que incesantemente viene a ser, donde movimiento y actividad son nociones modeladas ni más ni menos que por la primacía del ritual. Fuera del contexto ritual, las palabras sólo nos informan sobre esencias, y por lo tanto no nos dicen nada sobre su ser verdadero, su dharma, el cual se define precisamente por su finalidad (artha). Y la finalidad o el propósito de una palabra se manifiesta por la fuerza imperativa del lenguaje en el contexto del ritual, esto es, en la forma de prescripciones que empujan a realizar una acción. El lenguaje cobra sentido no al afirmar la existencia de algo sino al expresar la finalidad de una acción, de modo que son las relaciones, y no las esencias, las que nos dicen lo que necesitamos saber sobre tal o cual objeto. La verdad de ese objeto no es satya ("esencia", "sustancia"), sino kriyā ("actividad"), y por lo tanto sólo puede percibirse una vez que ese objeto queda subordinado a la compleja red de analogías rituales. Esto, dicho del sacrificio, es también cierto acerca del universo en su conjunto. "El sacrificio", explica Clooney, "es un microcosmos [...] Organizado alrededor del sacrificio, el sistema de Jaimini también organiza el universo alrededor de la verdad sacrificial". ${ }^{17}$ De este modo, para la escuela Mīmāṃsā el sacrificio acaba siendo toda una forma de conocimiento, y en ese sentido el estudio de las escrituras y su mensaje sobre el cosmos y el ser humano, sobre la naturaleza de la verdad y el absoluto, no puede darse al margen de una reflexión sobre la acción ritual, pues es justo en el carácter performativo del ritual que la verdad y el absoluto se ocultan.

El ya citado Abhinavagupta es otro caso ilustrativo. Así, a veces abiertamente, otras de modo muy sutil, éste contrasta la deidad que el arte de la interpretación recrea sobre el escenario de la práctica ritual con la deidad definida como "esencia" ( $s a t$, sattā). Esta precisión de carácter filosófico, que es también una crítica a ciertas escuelas de la tradición india (los jada- o śānta-brahmavādin-s, es decir, los "proponentes de un

tica o seereta" tiene su origen en la ingeniosa, pero forzada, interpretación de Śạkara, la cabeza de la corriente monista del Vedānta. Al respecto véase Renou 1946, pp. 5560; Gonda 1965, pp. 1-29; Falk 1986, pp. 80-97, y Olivelle (trad.) 1998, pp. lii-lvi.

${ }^{17}$ Clooney 1990, p. 125. 
brahman inerte, inactivo") ${ }^{18}$ y que por lo demás parece acercar peligrosamente la heterodoxia tántrica de Abhinavagupta a la heterodoxia por antonomasia del budismo, establece claramente la necesidad de pensar al absoluto más allá de su supuesta sub-sistencia, en pos de una visión más dinámica y expansiva. Y si en última instancia el absoluto no sub-siste entonces debe ser supra-esencial, eminente, entendiendo por esto, según la lógica misma del discurso abhinavaguptiano, no esencia hiperbólica, sino apenas ausencia de esencia, ausencia sin esencia. Para sustentar su interpretación Abhinavagupta echa mano de dos aspectos rituales inherentes a la revelación tántrica, a saber, la repetición de mantra-s (breves fórmulas, a veces simples monosílabos, imbuidas de poder) y la visualización de mandala-s (patrones geométricos diseñados para inducir la presencia de lo divino). ${ }^{19}$ Estos actos no son concebidos como meros ejemplos, sino como auténticos modelos para la reflexión, como sofisticados diagramas de un pensamiento ritualizado. En ambos casos, el resultado es el mismo: la interpretación se dinamiza hasta alcanzar la analogía final, también la más radical y desconcertante, a saber, aquella que confunde lo alto y lo bajo, lo sagrado y lo profano, lo divino y lo humano.

Y cuando el exegeta se vuelve consciente de esta paradoja y, yendo más lejos todavía, se atreve a abrazarla como la estrategia mejor preparada para hablar de lo supremo, su discurso comienza, de nuevo, a confundirse con la práctica ritual, de modo que la interpretación comienza

${ }^{18}$ Por ejemplo en su Parātrīśikālaghuvrtti, p. 16: “[El ser supremo o sat] es el reposo final de todas las cosas a lo largo del sendero impuro, es decir, el reposo al final del espectro completo de objetos inteligibles, desde el elemento agua hasta la ilusión. Al momento de este reposo final, todo [aparece como] una masa uniforme, inmortal, brahman que es ātman. [Yacer] sobre esto, tal es [la forma más elevada de] reposo entre los seguidores del Vedānta" (tathā jalatattvāder api māyātattvaparyantasya vedy arūpasyāśsddhādhvamadhyapātinah sarvasya saivāntyaviśrāntir ity antyaviśrāntikāle sarvam ekaghanam amrtam ātmabhūtam brahma. tāvati brahmavādinām viśrāntiḥ). En su comentario al Paramārthasāra (10-11), uno de los textos de juventud de Abhinavagupta, el exegeta Yogarāja (siglo XI) define explícitamente a los seguidores del Vedānta como proponentes de la doctrina del śānta-brahman: "A diferencia de los proponentes del brahman inactivo, el cual es prácticamente inerte, sin poder [nosotros defendemos una deidad], caracterizada por los poderes de voluntad, conocimiento y acción" (icchājñānakriyāśaktisvabhāvam eva na punặ śāntabrahmavādinām iva śaktivirahitạ̣ jadakalpam).

${ }^{19}$ En sus dos comentarios al Parātrīśikā Tantra, el extenso Vivarana y el conciso Laghuvrtti. 
a parecerse más a una puesta en escena, donde el pensar y el hacer se impregnan y confunden, y donde lo verdaderamente crucial es actualizar cíclicamente el misterio original.

\section{De la Palabra revelada a la palabra canónica}

Hasta aquí mi exposición se ha detenido sobre todo en la íntima relación que en la India antigua guardan el ars interpretandi y la Palabra de los Vedas, paradigma de la idea de revelación. Sin embargo, como se infiere a partir de la alusión a Abhinavagupta, la exégesis tiene una presencia igualmente decisiva entre las heterodoxias. Se puede no creer en el Veda, pero incluso entonces y con la misma importancia se cree en la interpretación como el recurso al alcance del hombre que mejor corresponde a la sacralidad de la Palabra. Esto es lo que hicieron, por ejemplo, los diversos cultos tántricos - el horizonte en el que se inscribe la obra de Abhinavagupta - al trasladar la autoridad de los Vedas a sus propias escrituras y deidades. El principio, empero, sigue siendo el mismo: la precedencia de la Palabra es al mismo tiempo el signo de una carencia: da testimonio de la inutilidad del concepto (vikalpa) frente a aquello que trasciende todo concepto (nirvikalpa). ${ }^{20}$

Como es bien sabido hubo en la India heterodoxias más radicales, aquellas que desconocieron por completo la autoridad de la revelación védica y, todavía más, sobre este repudio erigieron sus propias doctrinas. Me refiero desde luego al budismo y al jainismo, ambos movimientos ascéticos surgidos entre los siglos VI y v antes de nuestra era. La pregunta es obligada. ¿Rechazaron budistas y jainas la revelación védica abrazando en cambio una nueva revelación? En sentido estricto no fue así. Lo cierto, sin embargo, es que la crítica a la Palabra de los Vedas no supuso una crítica a la sacralidad de la Palabra en cuanto tal y al margen de un horizonte religioso específico. En realidad, el poder y la autoridad de los himnos védicos, con todo su halo de trascendencia y eternidad, fueron trasladados a la Palabra - al mismo tiempo humana y sobrehumana, histórica y atemporal - de caudillos espirituales como Buda y Mahāvīra.

${ }^{20}$ Abhinavagupta, Tantrasāra 1: “[...] y renunciar a lo que precede todo concepto es conformarse con una conciencia conceptual. Ahora bien, es el Absoluto mismo quien, siendo idéntico a la divinidad suprema, decide reducir a concepto (vikalpa) la luz de la conciencia" ([...] vikalpasamvidabhyāsasya avikalpāntatāparyavasānāt. vikalpāsaṃku-citasaṃvitprakāśarūpo hi ātmā śivasvabhāva). 
Desde esta perspectiva, la ruptura con el pasado védico significó el triunfo de una continuidad, puso de manifiesto un consenso en torno al valor supremo de la Palabra. Este consenso alcanza directamente al arte de la interpretación como el medio más apto para prestar oídos a la verdad, por encima incluso de la dicotomía ortodoxia-heterodoxia.

Por ejemplo, en el caso del budismo, las diversas corrientes dentro de la tradición del Pequeño Vehículo (hīnayāna) fundamentaron sus variables doctrinales en una interpretación del canon pāli, el cual se cree contiene los discursos pronunciados en vida por Buda. En particular, los seguidores de la escuela Sarvāstivāda a menudo recibieron el título de vaibhāșikā-s, en alusión precisamente al término que da nombre a los diversos comentarios (vibhasṣa ) sánscritos que redactaron a fin de explicar las enseñanzas contenidas en el Abhidharma. Asimismo, la literatura del Gran Vehículo (mahāyāna) comprende un sinfín de comentarios, en particular interpretaciones al Prajñāparamitasūtra, por no hablar de la sofisticada tradición exegética de corrientes como el Madhyamaka, el Yogācāra y el Vijñānavāda.

Ahora bien, como apenas sugerí, al citar los casos del budismo y el jainismo en realidad damos cuenta de un fenómeno mucho más amplio. La reverencia por la palabra revelada se entrecruza $-\mathrm{y}$ en algunos casos de hecho competirá - con la reverencia por la palabra canónica, esto es, lo dicho por figuras u obras a las que se atribuyen virtudes especiales, sean éstas de índole espiritual, sapiencial o moral, justificando así la labor interpretativa.

Canónico y, por lo tanto, digno de un tratamiento exegético fue por ejemplo el género conocido como sūtra, mencionado al principio de este ensayo. Así, a lo largo del periodo que va de los últimos siglos antes de la era común a los primeros de nuestra era fue gestándose una versión más sistemática, definitiva, de las diversas corrientes de pensamiento entonces en boga. El formato elegido para ello fueron formularios o manuales básicos, concebidos como una secuencia de "hilos" conductores (aquí la acepción más elemental de la palabra sūtra), donde la economía del lenguaje cumple una función capital no sólo en miras a la memorización sino asimismo, como bien apunta F. Chenet, por razones iniciáticas. ${ }^{21}$ En efecto, tal como los maestros brahmánicos buscaron siempre que sus enseñanzas mantuvieran su pureza y con ese fin estaban

${ }^{21}$ Chenet 1998, p. 1657. 
reservadas a un grupo selecto de adeptos, en un principio estos concisos formularios fueron enseñados a grupos reducidos de estudiantes, de modo que transmitidos por alguien lego resultaban incomprensibles. Dos cosas se desprenden de ello. Por un lado, tenemos aquí un testimonio de la expansión del modelo védico: la palabra canónica es investida con la autoridad de la Palabra revelada. Por el otro, en virtud de su naturaleza hermética o alusiva, el entendimiento correcto de los sūtra-s demanda un trabajo de apropiación en el que se espera estén entrenados los iniciados, de quienes depende por lo tanto que la estrategia protectora no sea contraproducente, esto es, que el mensaje original no caiga en el olvido o se vuelva ininteligible.

El origen de las grandes tradiciones filosóficas de la India descansa en este arduo trabajo de ampliación y decodificación de la palabra canónica a la luz del modelo derivado de la Palabra revelada. Estamos pues en el umbral del periodo escolástico de la filosofía india, cuya vitalidad se prolongaría hasta el siglo XII, en algunos casos, por ejemplo el de la escuela Nyāya, hasta el XVII. ${ }^{22}$ Empero, insisto, la exégesis propiamente, la del texto sagrado, se desdobló no sólo en la actividad interpretativa de comentaristas al interior de tradiciones filosóficas o religiosas. Lo mismo ocurrió, si bien quizá de manera un poco tardía, en el resto de las ciencias (śāstra). Ejemplos notables son la medicina y la teoría literaria. ${ }^{23}$

Como mencioné al principio del ensayo, en cualquiera de estos casos, la práctica que se impuso fue el estudio de textos revelados o canónicos por medio de glosas de orden puramente lingüístico y sólo a partir de este análisis elemental se desarrolló el comentario interpretativo, esto es, aquel que aspiraba a restaurar el sentido de un texto no sólo con el fin de hacer explícito su contenido sino asimismo ampliando o problematizando ciertos aspectos, casi siempre a la luz de posturas rivales. Como también apunté, el número de ramificaciones y variantes que el ars interpretandi sánscrito produjo a lo largo del periodo clásico es simplemente ad nauseam. Desde luego, los tiempos cambiaban y nuevas voces

${ }^{22}$ Cabe agregar que, en su fase final, el desarrollo de las diversas tradiciones filosóficas con base en el modelo exegético daría pie a todo un subgénero, el doxográfico, consagrado a resumir (samgraha) el propio discurso filosófico conforme a un patrón estable, ortodoxo, que norma y jerarquiza las diferentes perspectivas (darśana). El texto clásico es el Sarvadarśanasaṃraha de Sāyaṇa-Mādhava (s. XIV). Al respecto puede consultarse Halfbass 1988.

${ }^{23}$ Para un recuento del desarrollo histórico de esta última, véase Gerow 1974. 
canónicas se levantaban aquí y allá para proclamar verdades más acordes a los tiempos modernos. Así, la producción vertiginosa de comentarios y sub-comentarios a lo largo del periodo medieval se convirtió en un instrumento capital para vincular pasado y presente. Como muchas otras culturas tradicionales, fue interpretando y reinterpretando la Palabra que la India antigua intentó responder a las exigencias de la historia y a las demandas de nuevas audiencias.

Volviendo al caso de la filosofía, como bien ha subrayado K. Preisendanz, "sistematizar, evitar contradicciones, poner al día el léxico y la necesidad imperiosa de probar y justificar [...] los principios elementales de cada tradición a la luz del pensamiento filosófico contemporáneo, se volvieron tareas que impulsaron de manera decisiva el desarrollo de nuevas ideas a través de comentarios creativos". ${ }^{24} \mathrm{Al}$ respecto destaca, por ejemplo, el impacto que tuvo sobre el arte de la interpretación el surgimiento de la epistemología y la lógica, disciplinas tardías respecto a la añeja metafísica india. Esta demora determinó profundamente la labor de intérpretes y comentaristas, sobre quienes ahora pesaba la responsabilidad de actualizar los contenidos de las viejas doctrinas sobre el ser, el alma y la salvación a la luz de recursos argumentativos y persuasivos más actuales.

La importancia de este giro puede apreciarse a partir del modo como éste alcanzó incluso a una corriente por definición marginal y subterránea como la tántrica. Así, a partir del siglo IX, un grupo de iniciados en diversos cultos tántricos, todos oriundos de Cachemira, quienes además estaban versados en la tradición escolástica, emprendieron la ardua tarea de llevar el universo mágico de los tantras - con todo y sus deidades terribles, con sus jaculatorias (mantra) y diagramas místicos (mandala) a la arena política. Para ello era necesario, en primer lugar, recoger la esencia del discurso teísta, esotérico y litúrgico de un sinfín de textos revelados y articularlo alrededor de premisas doctrinales más homogéneas y definidas. Así fueron redactados compendios como el Śivasūtra (al que siguió atribuyéndose un origen divino) o la Spandakārikā. A esta primera fase en la construcción de un discurso canónico y sincrético acorde con los nuevos tiempos siguió el trabajo propiamente exegético, al que fueron incorporados los avances de disciplinas como la lógica y la epistemología, así como el legado de tradiciones insignes como la gramática (vyākaraṇa) y el análisis semántico (nirukta).

${ }^{24}$ Preisendanz 2008, p. 607. 
Desde luego hubo resistencia y la ortodoxia védica insistió en fundamentar el ars interpretandi en la Palabra de las verdaderas escrituras, los Vedas, relegando a un segundo plano lo dicho por "nuevos" autores, por más canónicos que fueran, y bajo esa premisa intentó descalificar los esfuerzos de otras tradiciones exegéticas, de modo que la aplicación de ingredientes modernos no secularizara los orígenes brahmánicos, rituales, de la exégesis sánscrita. Esta resistencia pone de manifiesto lo que en realidad fue un conflicto.

El mismo puede apreciarse, indirectamente, a partir del hecho de que el testimonio de las escrituras (śabda) fue incluido entre los criterios que sirven para dar validez a un conocimiento (pramāna). ${ }^{25}$ De entrada, la inclusión confirma la actualidad que el arte de la interpretación tuvo al interior del debate filosófico riguroso durante el periodo clásico, es decir, en un entorno en el que esperaríamos la emancipación de la razón. Otorgarle a la revelación el estatus de pramāna fue una forma de corresponder a la necesidad de legitimar la idea de que los textos sagrados son fuentes irreducibles y autosuficientes de conocimiento. Sin embargo, detrás de ello hay un fuerte componente crítico dirigido a cualquier otra forma de conocimiento y lenguaje, en particular, de nuevo, el discurso lógico. En efecto, detrás del uso exegético de la razón medra siempre una fuerte dosis de escepticismo respecto a la razón en cuanto tal.

Un caso particularmente ilustrativo es el del gramático Bhartṛhari (¿siglo vi?), quien reformuló la noción de śabda, y ahí mismo la de exégesis, a partir de premisas no dualistas (advaita) y en el contexto de una sofisticada reflexión sobre la naturaleza del lenguaje. Inspirado en un modelo inmanentista y recuperando algunas premisas básicas de la tradición védica, Bhartṛhari concibió el arte exegético como manifestación misma del poder (śakti) de la Palabra, identificada ésta con el Absoluto mismo (brahman) y, por consiguiente, criterio último de verdad. La Palabra mantiene su unidad y trascendencia aun en medio de su gradual proceso de diversificación en los cuatro Vedas, las subsecuentes tradiciones no reveladas pero canónicas (smrti) y, finalmente, en la labor de toda

25 El locus classicus es Nyāyasūtra 1.1.3: "La percepción, la comparación, la inferencia y el testimonio: éstos son los medios que dan validez a un conocimiento" (pratyakṣānumānopamānaśabdāh pramāṇāni). Dos aforismos más adelante el mismo Nyāyasūtra define śabda del siguiente modo: "Por testimonio se entiende la enseñanza [de una fuente] confiable" (āptopadeśạ śabdah), y no hay fuente más confiable que la Palabra revelada. 
clase de exegetas (darśana), quienes continúan y de hecho expanden el poder infinito de este śabda-brahman, ${ }^{26}$ de tal modo que lo que parece agente es en realidad instrumento: la palabra sobre la Palabra es siempre una forma de reflejo o recreación (anukāra) ${ }^{27} \mathrm{Al}$ tratar de penetrar en el sentido de la revelación védica, y en general del lenguaje, se va a la Palabra desde la Palabra. Entonces, una vez más, dada la preeminencia y precedencia de los Vedas, en sentido estricto no hay nada que no sea interpretación. Puesto que a un nivel esencial la razón (tarka) está subordinada a la revelación, ${ }^{28}$ hacer uso de la primera es interpretar la segunda. Ahora bien, aunque hay inclusión, hay asimismo una estricta gradación y una jerarquía rigurosa, aspectos determinados por la distancia que tal o cual interpretación mantenga respecto al mensaje védico. Este esquema le permite a Bhartrihari detectar aquellos casos en los que la razón se aleja de su fundamento más íntimo, es decir, cuando deja de servir a la revelación, dándole de hecho la espalda, ${ }^{29}$ para pretender por sí sola ser fuente de conocimiento, haciendo obsoleta la tarea interpretativa y elevando al máximo rango el pensamiento puramente lógico. ${ }^{30}$

Ante expresiones de un tradicionalismo tan arraigado como éste, con su enorme capacidad para reinventarse e imponer su verdad aun en

${ }^{26}$ Cf. Vākyapadīya 1.6-9. Al respecto además véase Halbfass 1991, pp. 37-40, 63-65.

27 Vākyapadīya 1.5: "Los grandes sabios retoman y recrean la revelación védica, y así, aunque ésta es una e indivisible por naturaleza, se transmite de muchas maneras" (prāptyupāyo "nukāraśca tasya vedo maharṣibhih | eko 'py anekavartmeva samāmnātah prithak prithak).

${ }^{28}$ Vākyapadīya, 1.129a: "La razón, fundamento del ser humano, no es sino el poder de las Escrituras" (śabdānām eva sā śaktis tarko yaḥ puruṣāśrayaḥ).

${ }^{29}$ Vākyapadīya 1.127a: "Cuando la razón no se opone a la ciencia revelada dota [al hombre] de visión" (vedaśāstrāvirodhī ca tarkaś cakṣur apaśyatām).

${ }^{30}$ Otro caso en la misma línea, donde la centralidad de la interpretación está en relación directa con una desestimación de la razón, es el que nos ofrece el gran pensador vedāntino Śamkara (siglos VII-VIII), cuya ortodoxia presupone una fe inquebrantable en lo dicho por los Vedas. De acuerdo con Śamkara, no hay esfera que no esté comprendida en la Palabra de los Vedas; ésta contiene la verdad tanto en lo convencional como en lo absoluto, y por lo tanto es un error confinarle a uno u otro ámbito. Esta postura universaliza también el recurso de la interpretación, condición necesaria para pensar la naturaleza absoluta de brahman y desde brahman todo lo demás. Aun cuando Śamkara piensa que el conocimiento (jñāna) está por encima de cualquier otro recurso o medio, al mismo tiempo su confianza plena en la revelación lo lleva a experimentar un profundo rechazo contra los alcances de la razón (tarka). Conocer no es, por lo tanto, lo mismo que razonar. Conocer es interpretar. Al respecto véase, en especial, Halbfass 1991, caps. 2, 3 y 5. 
medio de una sociedad en franca transformación, cabe preguntarse, con toda razón, si la exégesis sánscrita no fue después de todo un arte estéril, sometido a los designios de un grupo dominante, y por lo tanto imposibilitado para innovar y pensar con libertad. En suma, ¿estaba el exegeta indio condenado a repetir las verdades del pasado o, de lo contrario, ser acusado de heterodoxo? Definitivamente sería injusto afirmar que tan radical disyuntiva fue cierta en todos los casos, sin excepción. Más correcto es pensar en un horizonte general cuya aparente rigidez normativa nunca fue, en los hechos, impermeable al cambio, la innovación y aun la crítica. Incluso formando parte de la tradición, un amplio número de comentarios y obras exegéticas se las ingeniaron para ofrecer respuestas distintas a viejos problemas e incluso para descubrir nuevos problemas y consagrarse a su estudio y análisis. En un buen número de casos, esto se produjo a costa de la propia ortodoxia, a través de un discurso novedoso pero disfrazado de inofensiva elucidación en torno al significado de textos canónicos. ${ }^{31}$ No pocas veces tal disfraz se confunde con toda una defensa de la tradición. Esto es, por ejemplo, lo que Śaṃkara hace al comentar las Upanișad-s o el Brahmasütra: usar la autoridad de ciertos textos como vehículo para afirmar ideas propias, en este caso una forma extrema de monismo. Para reconocer que la novedad es, en muchos casos, un elemento constitutivo (y no una rareza) de un arte supuestamente ortodoxo como la interpretación, basta recordar que exactamente las mismas obras fueron usadas con fines doctrinales muy distintos. ${ }^{32} \mathrm{La}$ justificación, de nuevo, hay que hallarla en la idea misma de Palabra sacra, por definición inescrutable y por lo mismo semánticamente inabarcable por la palabra humana.

Entonces, en el terreno de la literatura puede traerse a colación el caso de Nīlakaṇțha, el célebre comentarista de la gran epopeya sánscrita, el Mahābhārata. Siendo un producto de la segunda mitad del siglo XVII, es de esperar que la interpretación de Nīlakanțha responda, en una medida importante, a necesidades ajenas a su fuente. ${ }^{33}$ ¿Cómo justifica nuestro

${ }^{31}$ Para el caso de la exégesis filosófica véase Preisendanz 2008, p. 606 y siguientes.

32 Además de Śạ̣kara, autores como Rāmānuja, Nimbārka y Vallabha, por citar los casos mejor conocidos, acudieron a estos mismos textos básicos a fin de defender sus doctrinas y de hecho inaugurar nuevas corrientes de pensamiento.

${ }^{33}$ No sólo eso. Como bien apunta C. Minkowski, Nīlakantha estaba bien "consciente de que se había embarcado en algo que no tenía precedentes tanto en contenido como en método" ("What Makes a Work 'Traditional'?”, p. 237). 
exegeta una lectura en varios sentidos alegórica y en la que no son inusuales los anacronismos $?^{34}$ La necesidad de un comentario así, se excusará Nīlakaṇtha apelando, paradójicamente, a un valor tradicional, descansa en que el Mahābhārata posee un "mensaje secreto" (gū dhārtha), nunca antes revelado. ${ }^{35}$

Así las cosas viene bien, para concluir esta sección, recordar las palabras de Filliozat sobre el riesgo de confundir al exegeta indio con el profesor universitario o el historiador de las ideas, en el deseo de que el primero responda a los criterios de objetividad que guían la actividad del segundo. En realidad, la diferencia entre ambos quehaceres es abismal, pues mientras que el segundo

busca comprender, bajo el espíritu científico, el sentido que un texto antiguo pudo haber tenido tanto en la conciencia de su autor como en el ambiente intelectual de su época, cuidando además no forzar demasiado su interpretación, por su parte el erudito ortodoxo no tiene ningún interés en restituir un estado antiguo [...]. Más bien, lo que le parece importante es presentar como un todo organizado su conocimiento completo, el cual contiene tanto la herencia antigua como su interpretación. ${ }^{36}$

\section{Interpretación y debate}

Dijimos antes que en la India antigua la Palabra es acto y que en un sentido extremo este lazo profundo entre el decir y el quehacer ritual desemboca en una escenificación de la Verdad sagrada. Siendo una tarea inherente a la recepción de la Palabra revelada, el ars interpretandi sánscrito no puede ser ajeno a esta representación litúrgica de la Verdad. Me parece que es posible ahondar en ello recuperando uno de los principales aspectos estilísticos - de hecho, el que más suele llamar la atenciónde la literatura de comentarios, sobre todo durante el periodo clásico, cuando la concepción védica de la Palabra fue extrapolada, como apenas vimos, a las más diversas doctrinas, incluyendo las heterodoxas. Me refiero desde luego a la textura polifónica, casi siempre bajo un espíritu

${ }^{34}$ Siendo ésta la principal crítica que algunos indólogos modernos - conforme a sus propias premisas "académicas" y científicas - han lanzado contra el trabajo de Nīlakantha, descartándolo como fuente confiable para el estudio de la gran epopeya.

35 Véase por ejemplo lo que dije antes citando a Yāska, el autor del Nirukta.

${ }^{36}$ Filliozat 1992, p. 92 (énfasis mío). 
controversial o polémico, de la exégesis sánscrita. Así, con esta última reflexión, intentaré mostrar no sólo la importancia que la práctica ritual tuvo para la exégesis sánscrita en sus orígenes, sino más importante aún su continuidad a través de la práctica del debate, evento concebido como una puesta en escena, como una reconstrucción dramatizada de la verdad.

De entrada conviene recordar que, de acuerdo con L. Renou, toda especulación en la India se remonta al brahmodya, ${ }^{37}$ literalmente "discusión en torno al brahman", es decir, las disputas o certámenes orales, en prosa o verso, que se celebraban en el marco del sacrificio védico con el fin de resolver diversos enigmas, por definición de carácter ritual y casi siempre con implicaciones cosmogónicas. Tan singular evento por lo general cobraba la forma de un diálogo entre sacerdotes que alternaban preguntas y respuestas sobre el origen, estructura y destino del cosmos. Más aún, la continuidad misma del universo dependía de esta dramatización que reproducía, al nivel del lenguaje, la lucha de los contrarios en el principio de los tiempos. Como es de esperar, para participar los dialogantes debían poseer un profundo conocimiento (e inspiración) en el arte de descubrir y establecer conexiones secretas (upanișad, bandhu $)^{38}$ entre los diferentes planos de la creación, así como entre las fuerzas que rigen la vida de todos los seres. Si bien los himnos del Rgveda, la porción más antigua del corpus védico, contienen unos cuantos testimonios de estas disputas, ${ }^{39}$ éstos se multiplican notablemente en el siguiente estrato del corpus, compuesto por las reflexiones de Brāhmaṇa-s y Upaniṣad-s, no casualmente los textos donde, como vimos, emergió el ars interpretandi sánscrito. Al respecto baste recordar las famosas escenas dialogadas y debates en la Bṛhadāranyaka y la Chāndogya Upaniṣad-s, las dos más antiguas. $^{40}$

${ }^{37}$ En su extenso ensayo "Le brahmodya védique". Más sobre el tema en Heesterman 1985 y Thompson 1997.

${ }^{38} \mathrm{Al}$ respecto véase antes nota 16.

${ }^{39}$ El mejor ejemplo, quizá el más antiguo que se ha preservado, es Rgveda 1.164, himno asociado con el legendario sacerdote Dīrghatamas.

${ }^{40}$ Por ejemplo, la discusión entre tres virtuosos recitadores védicos (Chāndogya Upaniṣad 1.8-11), o entre el rey Janaka y el sabio Yājñavalkya (Bṛhadāranyaka Upaniṣad 4.1-6), o entre este último y Maitrey1̄, su esposa (Bṛhadāranyaka Upaniṣad 2.4). También en la Bṛhadāranyaka Upaniṣad (3.1-9), es célebre el interrogatorio al que es sometido este mismo Yājñavalkya por varios interlocutores, entre ellos una mujer (Gārgī), en 
Como bien nota F. Chenet, esta disposición a debatir se intensificó con el surgimiento de los movimientos ascéticos, varios de ellos críticos del sistema védico, lo que vino a exacerbar la dimensión competitiva del antiguo brahmodya: ahora no sólo se discute para determinar quién es el mejor dentro de un sistema compartido de creencias; lo que se pone en escena es la rivalidad entre cosmovisiones antagónicas, a veces degenerando en insultos y calumnias. ${ }^{41}$ Algo sin embargo prevalece: se podrá poner en entredicho el valor del sacrificio, el axis mundi del hombre védico, mas esta afrenta a la tradición acaba siempre repitiendo el formato heredado del brahmodya, de modo que, al igual que la actividad exegética, la antigua práctica del debate logró trascender la dicotomía ortodoxia-heterodoxia. Encontramos un ejemplo muy tangible en el Carakasamhitā, gran compendio médico del los últimos siglos antes de la era común, donde un escéptico (nāstika) confronta y compite con un creyente (āstika), su rival lógico, a la vieja usanza védica. ${ }^{42}$

Ahora bien, contamos con un sinfín de testimonios que indican que, incluso desde la época de las Upaniṣad-s, estos despliegues de erudición habían dejado de celebrarse únicamente en la arena ritual y, auspiciados por príncipes y gobernantes, se habían ganado un sitio en la corte, trasladándose así a la arena política. El Mahābhārata, por poner un ejemplo, da cuenta de innumerables casos.

A pesar de que este nuevo escenario puede tomarse como indicio de que el brahmodya no era más él mismo un componente del sacrificio védico, lo que aquí me interesa resaltar es que no por ello el arte de debatir $-\mathrm{y}$ por lo tanto de interpretar - perdió su antiguo ingrediente dramático.

En efecto, sabemos que los debates celebrados en las cortes presuponían un alto nivel de teatralidad. ${ }^{43}$ Fueron un espectáculo, si bien uno

torno al significado de una serie de correspondencias que culmina en brahman mismo. En cuanto a los Brāhmaṇa-s, los ejemplos clásicos de la celebración de brahmodya-s proceden de los libros 10 y 11 en el Śatapatha Brāhmana.

${ }^{41}$ Chenet 1998, pp. 1660-1662. Ésta es la razón, cabe añadir, por la que en cierto momento el Buda prohíbe a sus simpatizantes involucrarse en tales eventos, a sus ojos no sólo nocivos sino en última instancia estériles (véase, por ejemplo, Dīghanikāya $1.33)$.

${ }^{42}$ Carakasamhitā 3.8.28: "Uno de los contendientes sostiene que hay renacimiento, mientras que el otro lo niega..." (ekasya pakșah punarbhavo stīti nāstīty aparasya...).

${ }^{43}$ Como bien sospecha Arnau 2008, pp. 16-17 (aun cuando no concuerdo con su idea de que el debate lógico "proviene del teatro"). No sorprende entonces que de la raíz 
muy sofisticado. Mudado a la corte, el antiguo brahmodya experimentó un gradual proceso de formalización a lo largo del periodo clásico. Algunas fases de este desarrollo pueden apreciarse en extensos pasajes del ya citado Carakasamhita y, finalmente, en el texto fundacional de la escuela lógica, el Nyāyasūtra, fechado hacia los primeros siglos de nuestra era. ${ }^{44} \mathrm{Y}$ es justo en el seno de la escuela Nyāya que las raíces rituales de la cultura del debate se transformaron en una ritualización del propio acto de construir conocimiento por medio de una exégesis polifónica. Elocuentemente rebautizado como vāda, "disputa", "controversia", el brahmodya védico fue así elevado al rango de ciencia, y como tal se establecieron reglas y principios que le dieran legitimidad, y normaran la intervención ahora no sólo de los contendientes (vädin) sino asimismo de jueces (parīkșaka), moderadores (madhyastha) y la propia audiencia.

De este modo, tal como los simpatizantes de las distintas corrientes de pensamiento, motivados por la posibilidad de obtener patronazgo, viajaban por toda la India y participaban en estas controversias con el fin no sólo de presentar sus teorías sino demostrar su legitimidad frente a las posturas de otros, la exégesis sánscrita adoptó como modelo no sólo la exposición de una doctrina propia, sino asimismo este intercambio polémico de ideas, escolástico resabio del ritualismo védico.

Esto significa que la interpretación sánscrita se desarrolló no sólo al amparo del valor superlativo otorgado a la Palabra; lo hizo además bajo este modelo de intercambio y competencia, el cual, insisto, tiene sus orígenes en la propia dimensión sacrificial de la revelación. En este sentido podría decirse que el ars interpretandi sánscrito reproduce la imperiosa necesidad de descubrir y afirmar un orden estable, si bien enigmático, en medio del cambio, la multiplicidad y la dicotomía; aspira, pues, a fijar una condición de equilibrio, en este caso intelectual y ya no cósmico, por medio del intercambio dialéctico de sistemas y posturas rivales.

Sea de manera sobreentendida o explícita, la íntima correspondencia entre interpretatio y disputatio se cristalizó, por así decirlo, a flor de texto, esto es, en la trama dialógica que subyace a la literatura de comentarios.

común del ritualismo védico, en especial de sus porciones dialogadas, brotara no sólo la práctica social del debate sino la tradición teatral india. Al respecto véase Lévi 1890, pp. 297-342; Keith 1916, pp. 146-151, y Gonda 1943, pp. 329 y siguientes.

44 En pāli, el diálogo entre el rey Menandro y el monje budista Nāgasena que da forma al Milindapañha (aprox. siglo II a. C.), representa también un ejemplo digno de notar. 
A fin de exponer tal o cual doctrina no basta, pues, apelar a la autoridad de la tradición, sea ésta revelada o canónica, sino que es además necesario presuponer o presentar - a veces en buena lid y con un espíritu objetivotodas aquellas posturas que sean susceptibles de entrar en contradicción con la propia. A éstas se da el nombre genérico de pūrvapakșa, "tesis preliminar", la cual puede entenderse también como "objeción" en virtud de su carácter controversial. Tras refutar la tesis preliminar, el exegeta procede a exponer la "tesis ulterior" (uttarapakșa) con la que espera alcanzar una posición doctrinal estable o tesis definitiva (siddhānta, nirnaya).

Aunque el modelo opera en todas las disciplinas (śāstra-s) como resultado de la propia universalidad del ars interpretandi, y en algunos casos influyó incluso en poetas y narradores, por razones obvias fue en el terreno filosófico donde alcanzó un mayor grado de desarrollo. Esto explica, por ejemplo, que la filosofía india, teatro vivo de toda clase de disputas, algunas intestinas otras perennes, sea impensable fuera del formato dialógico, el mismo en el que nunca dejó de agitarse la dimensión ritual de la Palabra. ${ }^{45}$

\section{A manera de conclusión}

A manera de conclusión digamos entonces que en la India sánscrita el arte de la interpretación no fue una actividad secundaria ni carente de profundidad ni ajena al devenir de la historia. Antes bien fue a través suyo que floreció el espíritu inquisitivo que caracteriza al periodo clásico en todos los ámbitos del saber, y en ese sentido puede considerársele como un importante factor de innovación y cambio. Para comprender esta centralidad fue necesario, sin embargo, remitirnos al pasado védico y revisar, por un lado, la relación entre interpretación y revelación, y, por el otro, entre interpretación y liturgia. Sólo recuperando este doble legado estuvimos en condiciones de apreciar en su verdadero alcance

45 A manera de ejemplo puede mencionarse la tensa y al mismo tiempo estimulante relación que en torno a la realidad o no del Absoluto mantuvieron los pensadores de la escuela Pratyabhijñā (Somānanda, Utpaladeva y Abhinavagupta) y la tradición lógica del budismo (representada por Dignāga y Dharmakīrti), o también el debate en torno a la existencia o no de un Dios creador entre las escuelas Mīmāṃsā y Nyāya. Famosas son también las polémicas que sostuvieron el Vedānta de Śạ̣kara y el Mīmāṃāa de Kumārila Bhaț̣a, o la tradición Sāṃkhya y el budismo Sarvāstivāda, o dentro del budismo la escuela Madhyamaka y el Yogācāra, y así ad infinitum. 
el elemento de continuidad que le es inherente a la tradición exegética sánscrita. Desde luego, en el aire quedaron varios asuntos. Por ejemplo evité trazar posibles (en varios casos, evidentes) paralelos con otras culturas, pues semejante tarea rebasaba con mucho el propósito de mi reflexión aquí. Como sea, me parece que incluso al guardar silencio al respecto, el artículo pone de manifiesto lo mucho que tienen en común, por un lado, la actividad interpretativa y el escolasticismo de la cultura sánscrita, y, por el otro, las tradiciones exegéticas grecolatinas, y más tarde, a lo largo del periodo medieval, cristianas, judías e islámicas. Más aún, potencialmente, este trabajo comparativo es extensible a algunas de las preocupaciones de la hermenéutica contemporánea. Desde esta perspectiva, la presente reflexión no puede sino concluir con la esperanza de que lo dicho contribuya a que otros se internen por estos y otros caminos, sean puramente indios o transculturales.

\section{BIBLIOGRAFÍA}

Fuentes primarias

Abhinavagupta, İśvarapratyabhijūāvimarśin̄̄, 3 vols., K. A. Iyer y K. C. Pandey (eds.), Delhi, Motilal Banarsidass, 1986.

_, Parātrimśikā Laghuvrtti, J. Zādoo (ed.), Shrinagar, Research Department, Jammu and Kashmir State, 1947.

_, Paramārthasāra, L. Bansat-Boudon (ed. y trad.), London, Routledge, 2011.

_, Parā-Trimśikā-Vivarana, R. Gnoli (ed. y trad.), Roma, Istituto Italiano per il Medio ed Estremo Oriente, 1985.

_, Tantrasāra, M. Rāma (ed.), Shrinagar, Research Department, Jammu and Kashmir State, 1918.

Bhartrahari, Vākyapadīya, K. A. Subramania Iyer (ed.), Pune, Deccan College, 1995.

Bṛhadāranyaka Upanișad, incluida en Daśopanișad-s, with the commentary of Sri Upanișadbrahmayogin, vol. 2, Madras, Adyar Library and Research Center, 1984.

Caraka, Carakasaṃhitā, J. T. Ācārya (ed.), Delhi, Munshiram Manoharlal, 4ª ed., 1981.

Chāndogya Upanișad, incluida en Daśopanișad-s, with the commentary of Srī Upanișadbrahmayogin, vol. 2, Madras, Adyar Library and Research Center, 1984.

Dīghanikāya, 3 vols., T. W. Rhys Davids y J. E. Carpenter (eds.), London, Pali Text Society, 1890-1911.

Gautama, Nyāyasūtra, 4 vols., G. Jha (ed.), Delhi, Motilal Banarsidass, 1984. 
NīlaKAN̦THA, Bhāratabhāvadīpa, incluido en la edición en 8 vols. del Mahābhārata, Pune, Citrashala Press, 1929-1936.

Rgveda, A. van Noten y G. B. Holland (eds.), Cambridge, Mass., Harvard University Press, 1994.

ŚAmKARA, Brahmasūtrabhāṣya, V. L. Panshikar (ed.), Bombay, Nirnaya Sagara Press, 1917.

_, Bṛhadāranyaka-Upanișad-Bhāṣya, E. Roer (ed. y trad.), Delhi, Bharatiya Kala Prakashan, 2000.

Śatapathabrāhmaṇa, A. Weber (ed.), Benares, Chowkhamba Sanskrit Series, 1964. YĀSKA, Nirukta, L. Sarup (ed. y trad.), Delhi, Motilal Banarsidass, 1967.

Fuentes secundarias

ARnau, J., Arte de probar. Ironía y lógica en India antigua, Madrid, FCE, 2008.

Bronkhorst, J., "Two Literary Conventions of Classical India”, Asiatische Studien, 45, 1991, pp. 210-227.

_, "Vārttika", Wiener Zeitschrift für die Kunde Südasiens, 34, 1990, pp. 123-146.

Chakravarti, P., Origin and Development of the Sämkhya System of Thought, Calcuta, Metropolitan Printing and Publishing House, 1951.

Chenet, F., "Le commentaire en Inde", André Jacob (dir.), Encyclopédie philosophique universelle, vol. 4, "Le discours philosophique", Paris, PUF, 1998, pp. 1656-1664.

Clooney, F., Thinking ritually, Rediscovering the Purva Mimamsa of Jaimini, Viena, De Nobili Research Library, 1990.

FALK, H., "Vedisch Upanișad", Zeitschrift der deutschen morgenldndischen Gesellschaft, 136-1, 1986, pp. 80-97.

Filliozat, P.-S., Le sanskrit, Paris, PUF, 1992.

Foucault, M., Naissance de la clinique, Paris, PuF, 1963.

Frauwallner, E., Geschichte der indischen Philosophie, 2 vols., Salzburgo, Otto Müller, 1953.

Ganeri, J., "Sanskrit Philosophical Commentary", Journal of Indian Council of Philosophical Research, 25-2, 2008, pp. 107-127.

Gerow, E., "Primary Education in Sanskrit: Methods and Goals", Journal of the American Oriental Society, 122-4, 2002, pp. 661-690.

_, "Indian Poetics", J. A. B. van Buitenen et al. (eds.), The Literatures of India: An Introduction, Chicago, University of Chicago Press, 1974, pp. 115-143.

GondA, J., "Bandhu in the Brāhmanas", Adyar Library Bulletin, 29, 1965, pp. 1-29.

_, "Zur Frage nach dem Ursprung und Wesen des indischen Dramas", Acta Orientalia, 19, 1943, pp. 329-453.

HADOT, P., "Der fortlaufende philosophische Kommentar in der Antike", W. Geerlings y C. Schulze (eds.), Der Kommentar in Antike und Mittelalter: Beiträge zu seiner Erforschung, Leiden, Brill, 2002, pp. 183-199.

HalBFASS, W., "The Sanskrit Doxographies and the Structure of Hindu Traditionalism", India and Europe, New York, SUNY Press, 1988, pp. 349-368. 
Halbfass, W., Tradition and Reflection. Explorations in Indian Thought, New York, SUNY Press, 1991.

Heesterman, J. C., "The Origin of the Nāstika", The Inner Conflict of Tradition. Essays in Indian Ritual, Kingship, and Society, Chicago, University of Chicago Press, 1985, pp. 70-80.

KeITH, A., "The Beginnings of the Indian Drama", Journal of the Royal Asiatic Society of Great Britain and Ireland, 1, 1916, pp. 146-151.

LÉvi, S., Le Théâtre Indien, Paris, É. Bouillon, 1890.

Minkowski, C., "What Makes a Work 'Traditional'? On the Success of Nīlakanthha's Mahābhārata Commentary", en F. Squarcini (ed.), Boundaries, Dynamics and Construction of Traditions in South Asia, Florencia, Universidad de Florencia, 2005, pp. 225-252.

Olivelle, P. (trad.), Upanișads, Oxford, Oxford University Press, 1998.

Pollock, S., The Language of the Gods in the World of Men. Sanskrit, Culture, and Power in Premodern India, Berkeley, University of California Press, 2006.

Preisendanz, K., "Text, Commentary, Annotation: Some Reflections on the Philosophical Genre", Journal of Indian Philosophy, 36, 2008, pp. 599-618.

Renou, L., “'Connexion' en védique, cause en 'bouddhique' ”, M. Natesan y H. G. Narahari (eds.), Dr. C. Kunhan Raja Presentation Volume, Madras, Adyar Library, 1946, pp. 55-60.

_, “Le brahmodya védique”, L’Inde fondamentale, Paris, Hermann, 1978, pp. 95116.

Thompson, G., "The Brahmodya and Vedic Discourse", Journal of the American Oriental Society, 117-1, 1997, pp. 13-37.

TubB, G., Scholastic Sanskrit, New York, Columbia University Press, 2007.

Verpoorten, J. M., Mīmāmnsā Literature, en J. Gonda (ed.), A History of Indian Literature, vol. 6, fasc. 5, Wiesbaden, Otto Harrassowitz, 1987. 